\title{
Strengths and Opportunity of Migrant Village Tourism Development in Indonesia
}

\author{
Bambang Supriadi ${ }^{1}$, Lusi Endang Sri Darmawati ${ }^{2}$ \\ ${ }^{1}$ University Of Merdeka Malang Indonesia \\ ${ }^{2}$ Vocational high School, Negeri 01 Panji Situbondo Indonesia
}

\begin{abstract}
Migrant worker problems occur due to limited job opportunities \& opportunities, income disparity and less productive use of income. Especially in Malang Regency in 2016 experienced an increase in the number of migrants by 21.8\%. The purpose of this research is a strategy to develop the tourism potential of Migrant Villages to increase job opportunities. This study will be carried out in Donomulyo Subdistrict in the south-east region (32 - $70 \mathrm{~km})$ from Malang City and concentrate on villages that have a potential migrant population who work abroad. The sampling technique is based on the random sampling method, number a sample of 69 with a 95\% confidence level. The analysis of this research uses the SWOT analysis (Strength, Weakness, Opportunity and Threats). Migrant Village, Donomulyo Subdistrict, has strengths, weaknesses, opportunities and threats, strength is its good panoramas, adequate infrastructure and then has a distinctive tradition of good artistic activities. The weaknesses are that the road access is not good enough, there is less attention, it is prone to disasters and the human resources are insufficient or insufficient. Strategies because of strengths but have opportunities, the strategic undertaken in cooperation with travel agents, further agro-tourism development strategies and increasing cultural tourism attractions and development of Bumdes (Business entities in the village). Furthermore, the next strategy is if it is strong but has challenges, the strategy is to make tour packages by branding tourist villages. However, if there is a weakness and there is a chance the strategy is to improve the infrastructure for the procurement of tourist signs, add to tourist spots and organize a tourist information Centre.
\end{abstract}

Keywords: Migrant Village, Productive, Tourism.

\section{INTRODUCTION}

The problem of migrant workers arises due to limited employment opportunities in the country, the occurrence of wage disparities that are far different from abroad and the utilization of income from abroad is less productive and leads to a more consumptive pattern. In particular, Malang Regency is the biggest contributor to international migration in East Java province. Not only low income but also the limited work available in the village causes family members to migrate. Malang Regency, the number of Indonesian Migrant Workers for countries in Asia (Hong Kong, Singapore, Malaysia and Taiwan) as a whole has increased by $21.8 \%$ in 2015 (1,947).

Seeing the problem of migrant workers above, a solution is needed to overcome the problem by creating new jobs through the Research of Productive Migrant Village Management Models Based on Tourism Services in the Framework of Creating Job Opportunities and utilizing the potential for migrant communities, because the lack of job opportunities in the village affects workers. migrants [1], thus this research activity will examine more deeply the indicators of Potential Tourism Attraction (DTW) through tourism pilots, including transportation services, food and beverage services, homestays, cultural entertainment, traditional attractions, guide services and uniqueness. other realms.

The urgency of the research in Malang Regency is as follows: First, Malang Regency still has a fairly high poverty rate above $11 \%$ [2], the second Malang Regency includes the pockets of Indonesian workers (TKI), where many migrant workers abroad are developing by $21.8 \%$, the third is recommendation Directorate General of Bina Kartasura, Ministry of Manpower of the Republic of Indonesia regarding productive migrant villages in Malang Regency [3], the four Malang Districts have high tourism potential so that they are included in the National Tourism Strategic Area (KSPN) but this potential has not been fully managed., so that a deeper study is needed to find a descriptive management model based on tourism businesses to create new job opportunities.

The research investigated the management pattern of tourism business-based descriptive which is closely related to the focus of the 2017-2045 RIRN goals, namely strengthening social capital that is competitive and following the 
Unmer Malang Strategic Plan in the field of superior entrepreneurship with the leading topic of business strategy development 2016-2021. The purpose of this research is the Productive Migrant Village Program is intended to create a productive society and prosperous TKI family in the village of origin of TKI.

\section{LITERATURE REVIEW}

Productive Migrant Villages (Desmigrative) are villages where most of the people work abroad, understand the system for placement and protection of workers both at home and abroad and can build productive independent businesses through the active role of the village government and other stakeholders. Tourism is a variety of tourism activities and is supported by various facilities and services provided by the community, businessmen, government and local governments.

A tourism business is a business that provides goods and/or services to meet the needs of tourists and to organize tourism. Indonesian Workers (TKI) or known as Migrants are Indonesian citizens who meet the requirements to work abroad in an employment relationship for a certain period and receive a wage [4]. Productive Migrant Village (Desmigrative) activities are focused on implementing mutual support and sustainability by including Information and Services for Migrants or TKI, Growing Productive Businesses, namely helping TKI, Developing Productive Businesses, Facilitating the Formation of Child Development and Development Community Caregivers [5].

Desmigrative activities can be focused on 4 (four) main activities whose implementation is to be integrated, mutually supportive and sustainable, while these activities are: Providing Information and Services for Migration or TKI, namely activities through the construction of a migration service and information centre, villagers who wish to work abroad the country gets labour market information services, job guidance, information about working abroad and document services for prospective migrant workers such as certificates or other documents [6].

Fostering and developing productive businesses, namely helping TKI and their families so that they have the skills and willingness to develop productive businesses through training, mentoring, and assistance for productive business facilities to marketing [6]. Facilitating the Formation of Community Parenting Children (Community Parenting), namely helping the community in forming a community whose job is to guide the families of TKI in terms of educating, caring for and guiding. Through this activity "Desmigrative Learning House", to educate and develop creativity [7] ; [8]. Facilitating the Formation and Development of Cooperatives / Financial Institutions, namely forming and developing cooperatives / financial institutions aimed at strengthening productive businesses.

\section{RESEARCH METHODS}

\subsection{Research Sites}

This study will be carried out in Donomulyo Subdistrict in the south-east (32 - $70 \mathrm{~km})$ from Malang City Indonesia and concentrate on villages that have a potential population of migrants or TKI who work abroad. The reason for choosing this location is because Malang Regency has the largest migrant village pockets in East Java, where most of the people work abroad and the village cannot build productive independent businesses.

\subsection{Sampling Technique}

The sampling technique is based on the random sampling method, with the Harry King Monogram [9], found a sample of 69 with a 95\% confidence level. The analysis of this study used a SWOT analysis (Strength, Weakness, Opportunity and Threats).

\section{RESULT AND DISCUSSION}

Tourism Potential of Donomulyo District, An overview of tourism activities in Donomulyo District is approached through data on the number of hotels/inns, tourism objects according to their type, the number of art groups, the number of cultural activities and the number of tourism support facilities. 2 groups, followed by a dance group of 1 group. Meanwhile, there are no other art groups in Do Omulyo sub-district. The largest number of sports facilities is volleyball with 22 volleyball followed by 15 pieces for soccer, 9 pieces for badminton and 1 tennis court. In Donomulyo District, there are no basketball and swimming sports facilities

Tourism Potential of Donomulyo District, An overview of tourism activities in Donomulyo District is approached through data on the number of hotels/inns, tourism objects according to their type, the number of art groups, the number of cultural activities and the number of tourism support facilities. 2 groups, followed by a dance group of 1 group. Meanwhile, there are no other art groups in Donomulyo sub-district. The largest number of sports facilities is volleyball with 22 volleyball followed by 15 
pieces for soccer, 9 pieces for badminton and 1 tennis court. In Donomulyo District, there are no basketball and swimming sports facilities

The number of tourist attractions in Donomulyo sub-district, Malang Regency, out of 10 villages in this sub-district has several tourist areas, namely beaches, baths, temples and sports fields, namely soccer fields, the most tourist attractions in this district have temples as many as 11 out of 6 villages and the highest is Sumberoto Village or and Donomulyo, then the most attractive points in this sub-district are 6 beaches and the highest is in Kedungsalam Village, namely 2 beaches, then the third serial number is a sports venue, namely 4 football fields and an average of 4 The village only has one, see the following table for details.

Table 1. Kind of Attraction Type

\begin{tabular}{clcccc}
\hline No. & Village / Sub-district & Beach & Swimming Pool & Temple & Football Field \\
\hline 1 & Sumberoto & 1 & 0 & 3 & 1 \\
2 & Purworejo & 0 & 1 & 1 & 0 \\
3 & Mentaraman & 1 & 0 & 1 & 0 \\
4 & Donomulyo & 0 & 0 & 3 & 1 \\
5 & Tempursari & 0 & 0 & 0 & 0 \\
6 & Tlogosari & 0 & 0 & 1 & 1 \\
7 & Kedungsalam & 2 & 1 & 2 & 1 \\
8 & Banjarjo & 1 & 0 & 0 & 0 \\
9 & Tulungrejo & 1 & 0 & 0 & 0 \\
10 & Purwodadi & 0 & 0 & 0 & 0 \\
\hline & Total & $\mathbf{6}$ & $\mathbf{2}$ & $\mathbf{1 1}$ & $\mathbf{4}$
\end{tabular}

Source: Village Office 2019

SWOT Analysis of Migrant Tourism Village, Tourism Analysis in Donomulyo Subdistrict has strengths, weaknesses, opportunities and threats, its strength is due to its good panoramas, adequate infrastructure and then has a distinctive tradition of good artistic activities. The weaknesses are that the road access is not good enough, there is less attention, it is prone to disasters and the human resources are insufficient or insufficient.

Apart from strengths and weaknesses, opportunities are also a preferred tourist attraction, a place for developing tourist attractions and cultural festivals. The challenge is that other tourist villages are more attractive with better road access, so if the strengths of the weaknesses are mentioned, the strategy below will be developed.

Doing a strategy where it is strong but still has strategic opportunities is carried out in collaboration with travel agencies, then the strategy of developing tourism and increasing cultural tourism attractions and developing Bumdes as well [10]. Furthermore, the next strategy is if it is strong but has challenges, the strategy is to make tour packages by branding tourist villages [5].

However, if there is a weakness and there is a chance the strategy is to improve the infrastructure for the procurement of tourist signs, add to tourist spots and organize a tourist information centre, for more details, see the matrix below. 
International Journal of Advances in Scientific Research and Engineering (ijasre), Vol 6 (12), December -2020

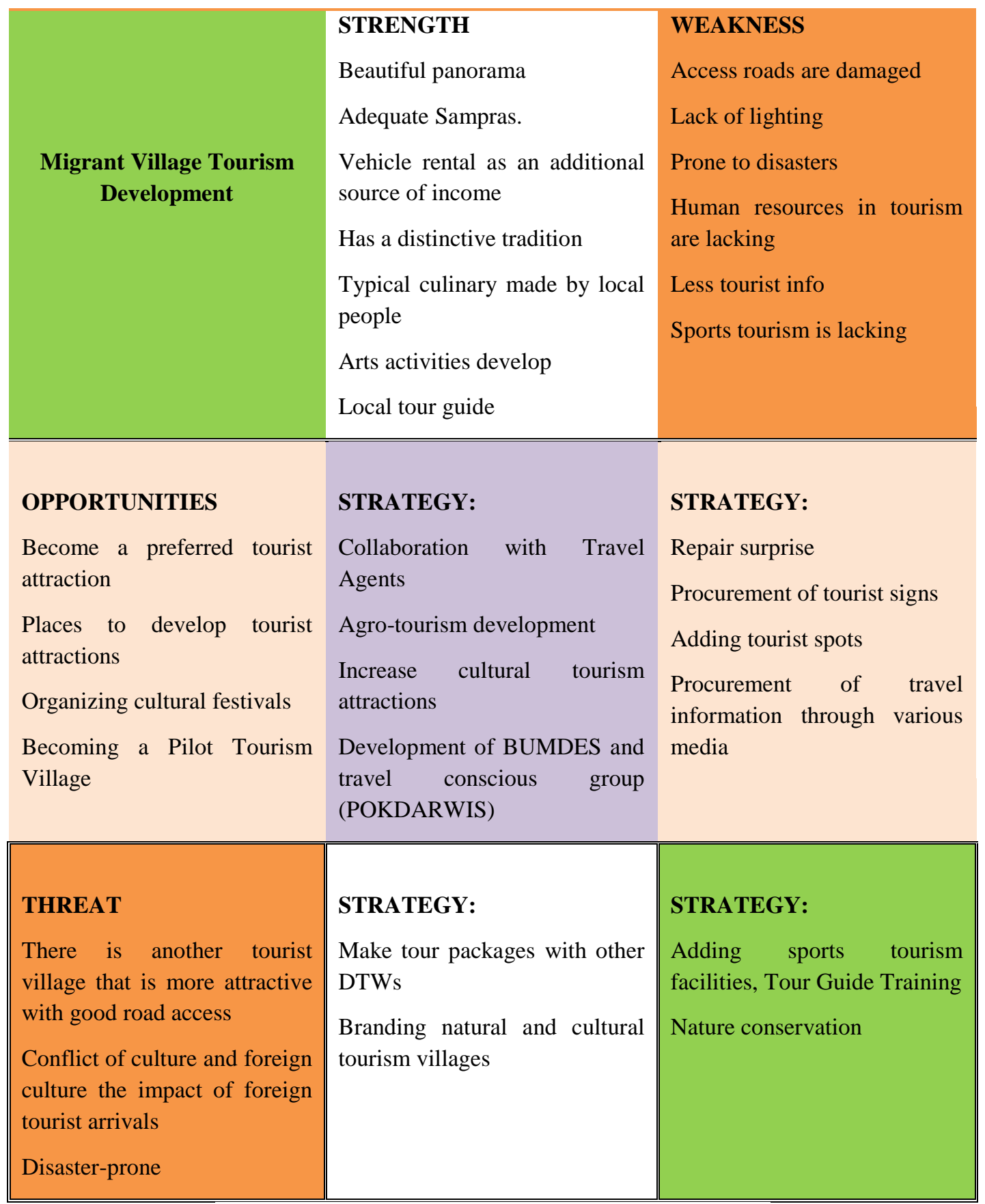

Figure 1. SWOT Analysis of Migrant Tourism Villages

\section{CONCLUSION}

The tourism potential in Donomulyo Subdistrict includes high tourism potential and a potential number of migrants. Tourism in Donomulyo District has strengths, weaknesses, opportunities and threats, its strengths because of its good panorama, adequate facilities and infrastructure, then it has a distinctive tradition of good artistic activities. The weaknesses are that the road access is not good enough, there is less attention, it is prone to disasters and the human resources are insufficient or insufficient.

Apart from strengths and weaknesses, opportunities are also a preferred tourist attraction, a place for developing tourist attractions and cultural festivals. The challenge is that other tourist villages are more attractive with better road access, so if the strengths and weaknesses are mentioned, then the strategy is developed below.

Doing a strategy where it is strong but still has strategic opportunities is carried out in collaboration with travel agencies, then the strategy of developing agro-tourism and increasing cultural tourism attractions and developing Bundes. Furthermore, the next strategy is if it is strong but has challenges, the strategy is to make tour packages by branding tourist villages.

However, if there is a weakness and there is a chance the strategy is to improve the infrastructure for the procurement of tourist signs, add to tourist spots and organize a tourist information centre, for more details, see the matrix below. 


\section{REFERENCES}

[1] Janta, H. L. Brown, P. Lugosi, and A. Ladkin, 2011. "Migrant relationships and tourism employment," Ann. Tour. Res., vol. 38, no. 4, pp. 1322-1343,

[2] BPS (2015). Jumlah Penduduk Miskin, Persentase Penduduk Miskin dan Garis Kemiskinan, 1970-2013. Dikutip tanggal. 12 Desember 2015 dari www.bps.go.id

[3] Astro, M. M. (2017). "Pemkab Malang Siapkan Dua Desa Migran Produktif," [Online]. Available: http://www.radiokanjuruhanfm.com/berita-daerah/805-pemkab-malang-siapkan-dua-desa-migran-produktif.html.

[4] Herman, N., \& Supriadi, B. (2017). Potensi Ekowisata Dan Kesejahteraan Masyarakat. Jurnal Pariwisata Pesona, 2(2), 112. https://doi.org/10.26905/jpp.v2i2.1578

[5] Aitken C. and C. M. Hall, (2010). "Migrant and foreign skills and their relevance to the tourism industry," Tour. Geogr., vol. 2, no. 1, pp. 66-86.

[6] Afrindo, A. (2014). "Strategi Advokasi Berjejaring Terhadap Tenaga Kerja Indonesia Oleh Serikat Buruh Migran Indonesia (Sbmi) Malang," J. Ilmu Pemerintah. Univ. Brawijaya Malang, vol. 7, no. 13, pp. 1-21,

[7] Giambi, C. M. Del Manso, T. Dalla Zuanna, F. Riccardo, A. Bella, M. G. Caporali, A. Baka, N. Caks-Jager, T. Melillo, R. Mexia, G. Petrović, and S. Declich, (2018). "National immunization strategies targeting migrants in six European countries," Vaccine,

[8] Nafi, M., \& Supriadi, B. (2017). Strategies of Tourism Development through Ecotourism Spectrum for Increasing Tourists' Visit. Rural Resarch and Palanning Group and Palanning Group, 75-85.

[9] Imran (2017). "Peran Sampling Dan Distribusi Data ( the Role of Sampling and Data Distribution in Communication Research Quantitative Approach )," Stud. Komun. Dan Media, vol. 21, pp. 111-126

[10] Anderson, B. (2010). "Migration, immigration controls and the fashioning of precarious workers," Work. Employ. Soc., vol. 24, no. 2, pp. 300-317. 